\title{
PENGARUH PELATIHAN OLEH KADER POSYANDU TERHADAP PRAKTEK IBU DALAM PEMBERIAN MAKANAN PENDAMPING ASI (MP-ASI)
}

\author{
Andi Tenri Abeng ${ }^{1}$, Linda Hardiyanti ${ }^{2}$ \\ Email: anditenri.abeng@umi.ac.id \\ ${ }^{1,2}$ Dosen Program Studi Diploma Tiga kebidanan FKM-UMI
}

\begin{abstract}
ABSTRAK
Makanan Pendamping ASI (MP-ASI) adalah makanan atau minuman yang mengandung zat gizi dan diberikan kepada bayi atau anak usia 6-24 bulan, guna memenuhi kebutuhan gizi selain dari ASI. MP-ASI diberikan sesuai dengan uur dari balita yaitu MPASI bayi umur 6-9 bulan, MP-ASI bayi umur 9-12 bulan dan MP-ASI bayi umur 12-24 bulan.Penelitian ini bertujuan untuk mengetahui pengaruh pelatihan oleh kader posyandu terhadap praktek ibu dalam pemberian MP-ASI di Desa Mallusesalo Kabupaten Wajo Tahun 2018.Jenis penelitian ini adalah kuasi eksperimental dengan rancangan perlakuan ulang (Pretest dan Posttest Group Design. Penelitian ini dilaksanakan di Desa Malusesalo Kabupaten Wajo Tahun 2018. Pengambilan sampel dalam penelitian ini akan menggunakan metode aksidental sampling yakni teknik penentuan sampel dengan cara pengambilan sampel yang dilakukan dengan kebetulan bertemu.Hasil penelitian ini yakni pelatihan oleh kader posyandu berpengaruh terhadap praktekibu dalam pemberian MP-ASI di Desa Mallusesalo Kabupaten Wajo $(\mathrm{p}=0,000)$. Adapun saran penelitian ini yakni perlupartisipasiaktif masyarakatuntukmendukungperan kader dalam menjalankan perannya saat kegiatan posyandu. Perlu peningkatan peran aktif kader dalam program-program peningkatanketerampilankader yangdilaksanakan olehpuskesmas dan dinas kesehatan.Meningkatkanprogrampelatihankaderyang bertujuan untuk meningkat keterampilan dan motivasi kader serta adanya supervisi dari puskesmas berupa monitoring dan evaluasi pada tiap kegiatan kader saat posyandu.
\end{abstract}

\section{Kata kunci: Pelatihan, Kader Posyandu, Praktek Pemberian MP-ASI}

\section{INFLUENCE OF TRAINING BY CADRE OF INTEGRATED HEALTH POST TOWARDS MOTHER'S PRACTISE IN GIVING COMPLEMENTARY FOOD FOR BREAST MILK}

\begin{abstract}
ABSTRAC
ASI complementary foods (MP-ASI) are foods or drinks that contain nutrients and are given to infants or children aged 6-24 months, to meet nutritional needs other than breast milk. MP-ASI is given in accordance with the age of the toddler namely MPASI infants aged 6-9 months, MP-ASI infants aged 9-12 months and MP-ASI infants aged 12-24 months. This research aims to discuss training research by posyandu cadres for practice mother in giving MP-ASI in Mallusesalo Village, Wajo Regency in 2018. This type of research is quasi-experimental with re-assistance provision (Pretest and Posttest Group Design. This research was conducted in Malusesalo Village in Wajo Regency in 2018. Accidental sampling is a sampling technique by means of sampling techniques took a sample conducted using meetings. The results of this study were training by posyandu cadres against the practice of mothers in providing MP-ASI assistance in Mallusesalo Village, Wajo District $(p=0,000)$. cadres in carrying out the activities of the posyandu activities were active cadres in cadres enhancing programs implemented by cadres implemented. by the puskesmas and the health department. Improving the program cadre training to improve the skills and motivation of cadres and
\end{abstract}


to choose supervision from puskesmas in the form of monitoring and possibly in every cadre activity during posyandu.

Keywords: Training, Posyandu Cadre, Practice of Giving MP-ASI

\section{PENDAHULUAN}

Masalah gizi pada umumnya merupakan masalah kesehatan dengan cara penanggulangannya bukan hanya dengan pendekatan medis maupun pelayanan kesehatan. Ada berbagai penyebab yaitu, pendekatan penanggulanganmasalah gizi melibatkan beberapa lintas sektor yang bekerjasama dengan menanggulangi masalah gizi.

Gizi pada anak sangat berperan bagi tumbuh kembang anak, tujuan pemberian gizi yang baik pada anak yaitu mencapai tumbuh kembang anak yang cerdas dan kuat dan jika kekurangan gizi dapat menyebabkan gangguan pertumbuhan dan perkembangan yang tidak diatasi sejak dini akan berkelanjutan hingga dewasa (Supariasa, dkk 2016).

Status gizi anak dipengaruhi oleh asupan gizi yang didapat ibu saat hamil maupun sesudah bayi lahir. Secara nasional, prevalensi pada tahun 2018 gizi buruk adalah $3,9 \%$ dan gizi kurang sebesar $13,8 \%$. Kondisi ini belum mencapai target RPJMN 2019 yaitu sebesar $17 \%$. Sedangkan prevalensi status gizi pendek meningkat pada tahun 2013 yaitu sebesar 19,2\% dibandingkan dengan tahun 2007 sebesar 18,0\%. Hal ini menunjukkan bahwa masalah gizi masih merupakan masalah kesehatan masyarakat (Riskesdas,2018).

Usia 0-24 bulan merupakan periode masa kritis dalam pertumbuhan dan perkembangan anak, karena di masa ini periode tumbuh dan kembang anak yang paling optimal baik untuk intelegensi maupun fisiknya. Periode inidapat juga terwujud apabila anak mendapatkan asupan gizi baik makro dan mikro yang baik sesuai kebutuhannya secara optimal (Derapheak, 2013).

Gangguan pertumbuhan dan perkembangan menurut WHO menyoroti pentingnya periode 1000 hari kehidupan. Intervensi perbaikan gizi sebagai yang utama dan tujuan harus diakses oleh semua individu dan rumah tangga terutanma kehamilan yang pertama, dua tahun kehidupan dan pada saat sakit. Pertumbuhan dan perkembangan harus ditempatkan pada pentingnya menyediakan lingkungan nutrisi yang tepat waktu dan pemberian MP-ASI yang baik selama 1000 hari kehidupan (Mahmudiono, 2017).

Pemberian MP-ASI juga berperan penting dalam pertumbuhan dan perkembangan bayi pada usia setelah 6 bulan. Beberapa penelitian menyebutkan bahwa maslah gizi pada bayi dan anak disebabkan kebiasaan ASI dan MP-ASI yang tidak tepat. Selain itu, adanya kebiasaan pemberian makanan bayi yang tidak tepat seperti : pemberian makanan yang terlalu awal atau terlambat, makanan yang diberikan tidak sesuai porsi dan frekuensi yang kurang (Motsa, Ibisoma, Odimegwu, 2016). Pemberian makanan yang terlalu lambat akan menyebabkan bayi mengalami kesulitan mengunyah, tidak menyukai makanan padat dan kekurangan gizi.

Berdasarkan SDKI 2012 menunjukkan bahwa $71,5 \%$ anak usia 6-24 bulan mendapatkan makanan dari sayuran dan buah yang kaya vitamin A dan sebesar 37\% diberi makan sesuai dengan semua praktik IYCF (Infant and Young Child Feeding Practice) yang direkomendasikan (produk susu atau susu dengan keragaman yang memadai dan frekuensi makan). Hal ini menunjukkan bahwa masih ada anak yang belum mendapatkan makanan yang kaya vitamin A dan pemberian MP-ASI yang belum sesuai standar WHO (Cooperative assistance and Relief Everywhere).

Menurut Kementrian RI, 2014, peningkatan derajat kesehatan masyarakat salah satunya dilakukan melalui peningkatan peran serta masyarakat termasuk swasta dan masyarakat madani. Kegiatan yang dilakukan untuk meningkatkan peran serta masyarakat di antaranya adalah menggerakkan masyarakat untuk memanfaatkan posyandu sebagai salah satu sarana pelayanan kesehatan dasar yang tumbuh dan berkembang di masyarakat. Salah satu yang berperan serta dalam menggerakkan masyarakat adalah petugas kesehatan. 
Pender et al (2002) menerangkan bahwa salah faktor pendorongterbentuknya perilaku kesehatan adalah pengaruh hubungan interpersonal.Pengaruh interpersonal dalam hal ini adalah kesadaran mengenai perilaku,kepercayaan atau pun sikap terhadap orang lain. Sumber utama pengaruhinterpersonal pada perilaku promosi kesehatan adalah keluarga dan petugaskesehatan. Pengaruh interpersonal meliputi norma (harapan dari orangorangyang berartidukungan sosial (dorongan instrumental dan emosional) danmodeling (pembelajaran melalui mengobservasi perilaku khusus seseorang).

Berdasarkan teori perilaku di atas maka petugas kesehatan yangdapat berpengaruh dalam perilaku masyarakat adalah orang mempunyai hubunganinterpersonal yang baik dengan masyarakat tersebut. Kader sebagai perwakilandari petugas kesehatan memiliki peran yang penting dalam mempengaruhiperilaku msyarakat sebagai upaya untuk meningkatkan status kesehatanmasyarakat. Kader kesehatan adalah seseorang yang dipilih oleh masyarakat danbertugas meningkatkan kesehatan masyarakat dengan sukarela (Gunawan 1980dalam Zulkifli 2003). Peran kader dalam menjalankan tugasnyasebagai pemberi pendidikan kesehatan tersebut berpengaruh besar terhada perilaku yang ada di masyarakat.

Pemberian pendidikan kesehatan oleh kader bertujuan untukmengubah perilaku yang ada di masyarakat (Sumijatun et al, 2005). Perubahanperilaku dapat dilihat dari komponen-kompenen perilaku yaitu pengetahuan, sikapdan praktek. Pendidikan kesehatan akan meningkatkan pengetahuan tehadap suatuobjek. Peningkatan pengetahuan akan membuat seseorang melakukan penilaianatau bersikap terhadap objek tersebut dan proses selanjutnya orang tersebut akanmelaksanakan atau mempraktekan apa yang telah diketahui dan disikapinya(Notoatmodjo, 2007).

Saat ini jumlah kader di posyandu desa Mallusesalo sebanyak 12 kader dengan jumlah bayi dan balita sebanyak 106 orang dan masih ada 3 orang balita yang mengalami gizi buruk. Kegiatan-kegiatan yang dilakukan kader antara lain adalah membantu kegiatanposyandu, melakukan pendidikan kesehatan saat posyanduberlangsung dan menggerakan ibu-ibu untuk aktif datang ke posyandu.

Pendidikan kesehatan mengenai pemberian MP-ASI yang dilakukan oleh kaderakan meyebabkan perubahan perilaku di masyarakat. Perubahan perilaku tersebutsalah satunya dapat dilihat dari praktek ibu dalam pemberian MP-ASI. Oleh karena itu penulistertarik melakukan penelitian ini untuk menganalisis pengaruh Pelatihan oleh kader terhadap praktek ibu dalam pemberian MPASI khususnyadi wilayah keja posyandu Desa Mallusesalo Kabupaten Wajo.

\section{METODE}

\section{Lokasi dan Rancangan Penelitian}

Penelitian ini dilaksanakan di desa Mallusesalo Kabupaten Wajo Tahun 2019. Jenis penelitian ini adalah kuasi eksperimental dengan rancangan perlakuan ulang (Pretest dan Posttest Group Design), yang memungkinkan peneliti dapat menguji perubahan-perubahan yang terjadi setelah adanya perlakuan.

\section{Populasi dan Sampel}

Populasi dalam penelitian ini adalah semua ibu yang memiliki bayi $0-24$ bulan diwilayah kerja Posyandu Desa Mallusesalo Kecamatan Sabbangparu Kabupaten Wajo. Jumlah sampel sebanyak 50 orang yang diambil menggunakan metode aksidental sampling yakni teknik penentuan sampel dengan cara pengambilan sampel yang dilakukan dengan kebetulan bertemu.

\section{Pengumpulan Data}

Data primer diperoleh langsung dari responden melalui observasi langsung secara sebelum dan setelah perlakuandengan menggunakan lembar observasi yang telah disusun sebelumnya sesuai dengan tujuan penelitian. Data sekunder diperoleh dari instansi yang terkait dengan tujuan penelitian seperti Dinas Kesehatan Kabupaten Wajo dari pencatatan bidan desa.

\section{Analisis Data}

Analisis data univariat dilakukan untuk melihat gambaran distribusi frekuensi dengan persentase tunggal untuk masingmasing variable penelitian terkait dengan tujuan penelitian dan disajikan dalam bentuk tabel distribusi frekuensi . Analisis data bivariat dilakukan untuk mengetahui pengaruh pelatihan kesehatan oleh kader posyandu terhadap praktek ibu dalam pemberian MP- 
ASI dengan menggunakan uji t. Selisih nilai mean hasil uji $t$ digunakan untuk membandingkan perubahan yang terjadi

\section{HASIL PENELITIAN \\ Analisis Univariat}

Tabel 1 menunjukkan kelompok umur ibu yang tertinggi adalah kelompok umur 2529 tahun yakni sebanyak 20 orang (40\%). Adapun kelompok umur terendah adalah kelompok umur $\geq 40$ tahun yakni 3 orang (6\%). Pendidikan ibu yang ikut dalam penelitian ini bervariasi dari tidak sekolah sampai Diploma/PT. Pendidikan ibu yang tertinggi adalah tamat SLTP yakni 16 orang (32\%). Adapun pendidikan terendah adalah tidak sekolah yakni 2 orang (4\%). Mayoritas ibu dalam penelitian ini adalah ibu rumah tangga yakni 35 orang $(70 \%)$. Hanya 3 orang yang berprofesi sebagai wiraswasta (3\%). Mayoritas ibu dalam penelitian ini adalah ibu multipara yakni sebanyak 29 orang (58\%). Sedangkan ibu primipara sebanyak 21 orang $(42 \%)$.

Hasil Analisis univariat variabel yang diteliti memperlihatkan terjadinya peningkatan praktek ibu dalam pemberian MP-ASI sebelum dan setelah diberikan intervensi pelatihan kesehatan. Sebelum dilakukan intervensi ibu yang memiliki praktek pemberian MP-ASI baik sebanyak 23 responden (46\%), sedangkan ibu yang memiliki praktek pemberian MP-ASI kurang sebanyak 27 responden (54\%). Setelah dilakukan pelatihan oleh kader posyandu. Sebagian besar respoden memiliki praktek pemberian MP-ASI yang baik yakni sebanyak 39 responden (78\%), sedangkan sebanyak 11 responden $(22 \%)$ yang memiliki praktek pemberian MP-ASI kurang.

\section{Analisis Bivariat}

Berdasarkan Tabel 2, Sebelum intervensi, skor rata-rata praktek ibu dalam pemberian MP-ASI adalah 19,68 sedangkan setelah intervensi adalah 24,00. Terjadi peningkatan skor praktek ibu dalam pemberian MP-ASI sebesar 21,95\%. Hasil uji statistik menunjukkan bahwa terdapat perbedaan yang signifikan pada praktek ibu dalam pemberian MP-ASI sebelum dan setelah intervensi dengan pelatihan kesehatan $(p=0,000)$. Ini berarti ada pengaruh pelatihan oleh kader posyandu terhadap praktek ibu dalam pemberian MP-ASI. sebelum dan setelah intervensi pelatihan kesehatan terhadap praktek ibu dalam pemberian MP-ASI.

\section{PEMBAHASAN}

Metode dan teknik pelatihan dalam kesehatan atau pendidikan kesehatan adalah cara dan alat bantu yang digunakan oleh pelaku promosi kesehatan untuk menyampaikan pesan kesehatan atau mentransformasikan perilaku kesehatan kepada masyarakat. Salah satu metode dalam penyampaian pesan adalah metode ceramah atau penyuluhaan dan simulasi. Metode ini baik untuk sasaran yang berpendidikan tinggi maupun rendah (Notoatmodjo, 2007).

Hasil penelitian menunjukkan bahwa terdapat pengaruh pelatihan oleh kader terhadap praktekibu dalam pemberian MPASI. Sebelum intervensi sebanyak $27 \mathrm{ibu}$ memiliki praktek pemberian MP-ASI kurang (54\%), sedangkan Ibu yang memiliki praktek pemberian MP-ASI baik yaitu 23 ibu (46\%). Setelah dilakukan intervensi, Sebagian besar respoden memiliki praktek pemberian MP-ASI yang baik yakni sebanyak 39 responden (78\%), sedangkan sebanyak 11 responden (22\%) yang memiliki praktek pemberian MPASI kurang.

Sebelum intervensi, skor rata-rata praktek ibu dalam pemberian MP-ASI adalah 19,68 sedangkan setelah intervensi adalah 24,00. Terjadi peningkatan skor praktek ibu dalam pemberian MP-ASI sebesar 21,95\%. Hasil uji statistik menunjukkan bahwa terdapat perbedaan yang signifikan pada praktek ibu dalam pemberian MP-ASI sebelum dan setelah intervensi dengan pelatihan kesehatan $(\mathrm{p}=$ 0,000 ). Ini berarti ada pengaruh pelatihan oleh kader posyandu terhadap praktek ibu dalam pemberian MP-ASI.

Hasil penelitian ini sesuai dengan teori Green(1980) dan teori Penderet al (2002). Green (1980) dalam Notoatmodjo(2007) menyebutkan bahwa salah factor pendorong yang mempengaruhi perilaku masyarakat salah satunya adalah petugas kesehatan atau petugas lain yang merupakan referensi dari perilaku masyarakat.

Teori Pender et al(2002) menerangkan bahwa salah faktor pendorong terbentuknya perilaku kesehatan adalah adanya 
pengaruh hubungan interpersonal. Kader merupakan sumber referensi rujukan masyarakat, dipercaya oleh masyarakat dan memiliki hubungan yang dekat dengan masyarakat karena kader tersebut merupakan bagian dari masyarakat. Kader adalah orangyang berpengaruh terhadap perubahan perilaku masyarakat. Peran kader dalam menjalankan tugasnya sebagai pemberi pendidikan kesehatan saat posyandu berlangsung berpengaruh besar terhadap perilaku yang ada dimasyarakat.

Pelatihan kesehatan adalah proses untuk merubah perilaku peserta didik dengan tujuan untuk peningkatan status kesehatan, memberikan suatu pengetahuan dengan harapan untuk mengetahui dan mengubah perilaku seseorang sebagai upaya peningkatan status kesehatan (Sumijatun et al, 2005). Peningkatan nilai praktek pemberian MP-ASI dalam penelitian ini semakinmendukung bahwa terdapat pengaruh pendidikan kesehatan oleh kader terhadap praktekibu dalam pemberian MP-ASI.

Tingkat pendidikan ibu dalam penelitian inimenunjukan tingkat pendidikan dasarpaling banyakyaitu32 \%.Tingkat pendidikan merupakan salah satu faktor yang

\section{DAFTAR PUSTAKA}

Cooperative for Asistance and Relief Everywhere, I. 2010. Infant And Young Child Feeding Practices : Collecting and Using Data : A Step-by Step Guide. Boston : Center for Global Health and Internasional Development, Boston University.

Darapheak C, Takano T, Kizuki M, Nakamura K, Seino K. 2013. Konsumption of animal source foods an dietary diversity reduce stunting in children in Cambodia. Int Arch Med.

Kementrian Kesehatan Republik Indonesia. 2018. Riset Kesehatan Dasar (Riskesdas) 2018. Jakarta: Badan Penelitian dan Pengembangan Kesehatan Kementrian Kesehatan Republik Indonesia.

Mahmudiono. 2017. Household dietary diversity and child stunting in East Java, Indonesia. Depatemen of Nutrition, Faculty of Public Health, Universitas Airlangga, Indonesia menentukan keberhasilan proses pendidikan kesehatan. Tingkat pendidikan akan menentukan tingkat inteligensi individuyang akan menentukan daya tangkap individu dalam menerima informasi yang disampaikan (Notoatmodjo,2007). Tingkat pendidikan ibu paling banyak berada ditingkat Sekolah Dasar. Tingkat pendidikan tersebut dapat menyebabkan ibu dapat memahamiinformasiyang diberikan oleh kader sehingga membuat penilaian praktek ibu dalam pemberian MP-ASI menjadi lebih baik

\section{KESIMPULAN DAN SARAN}

Berdasarkan hasil penelitian dapat disimpulkan bahwa pelatihan oleh kader posyandu berpengaruh terhadap praktek ibu dalam pemberian MP-ASI di desa Mallusesalo Kabupaten Wajo. Adapun saran dari penelitian ini yakni perlu partisipasi aktif masyarakat untuk mendukung peran kader dalam menjalankan perannyasaat kegiatan posyandu, meningkatkan peran aktif kader dalam program-program peningkatan keterampilan kader yang dilaksanakan olehpuskesmas dan dinas kesehatan, serta adanya supervisi dari puskesmas berupa monitoring dan evaluasi pada tiap kegiatan kader saat posyandu.

Notoatmodjo. 2007. Promosi Kesehatan dan Ilmu Perilaku. Jakarta: Rineka Cipta

Pender et all. 2002. Health Promotion in Nursing Practice. Prentice Hall.

Prabantini, Dwi. 2010. A-Z Makanan Pendamping ASI. Yogyakarta: CV Andi Offset.

Pender et all. 2002.Health Promotion in NursingPractice. PrenticeHall.

Potter, Patricia A dan Anne Griffin Perry. 2005. Buku Ajar Fundamental Keperawatan. Volume 1. Jakarta: EGC

Syafeietall.2008.

PemberdayaanKaderdalamRevitalisasi Posyandudi Kabupaten BatangHari.httpwww.lrckmpk.ugm.ac.ididUPPDF_workingNo.14_M_Syafei_04_08 .pdf. (Diakses 1 April2018)

Sumijatun et all. Konsep Dasar Keperawatan Komunitas. 2005. Jakarta: Penerbit Buku Kedokteran EGC 
Supariasa. 2016. Penilaian status Gizi. Jakarta : Penerbit Buku Kedokteran EGC

Sutomo, Budi dan Anggraini, Dwi Yanti. 2010. Makanan Sehat Pendamping ASI.Jakarta: Demedia Pustaka.
Zulkifli. 2003. Posyandu dan Kader Kesehatan. httprepository.usu.ac.idbitstream1234 5678937531fkm-zulkifli1.pdf. (Diakses 5 April 2018 ). 


\section{Lampiran}

Tabel 1. Distribusi Karakteristik Responden di desa Mallusesalo Kabupaten Wajo Tahun 2019

\begin{tabular}{|c|c|c|c|}
\hline Kelompok Umur (tahun) & Jumlah (n) & \multicolumn{2}{|c|}{ Persen $(\%)$} \\
\hline $20-24$ & 11 & \multicolumn{2}{|c|}{22,0} \\
\hline $25-29$ & 20 & \multicolumn{2}{|c|}{40,0} \\
\hline $30-34$ & 12 & \multicolumn{2}{|c|}{24,0} \\
\hline $35-39$ & 4 & \multicolumn{2}{|c|}{8.0} \\
\hline$\geq 40$ & 3 & \multicolumn{2}{|c|}{6,0} \\
\hline Jumlah & 50 & \multicolumn{2}{|c|}{100,0} \\
\hline Pendidikan & Jumlah (n) & \multicolumn{2}{|c|}{ Persen $(\%)$} \\
\hline Tidak sekolah & 2 & \multicolumn{2}{|c|}{4,0} \\
\hline Tamat SD & 13 & \multicolumn{2}{|c|}{26,0} \\
\hline Tamat SMP & 16 & \multicolumn{2}{|c|}{32,0} \\
\hline Tamat SMA & 10 & \multicolumn{2}{|c|}{20,0} \\
\hline Diploma/PT & 9 & \multicolumn{2}{|c|}{18,0} \\
\hline Jumlah & 50 & \multicolumn{2}{|c|}{100,0} \\
\hline Pekerjaan & Jumlah (n) & \multicolumn{2}{|c|}{ Persen $(\%)$} \\
\hline URT & 35 & \multicolumn{2}{|c|}{70,0} \\
\hline PNS & 5 & \multicolumn{2}{|c|}{10,0} \\
\hline Pegawai Swasta & 7 & \multicolumn{2}{|c|}{14,0} \\
\hline Wiraswasta & 3 & \multicolumn{2}{|c|}{6,0} \\
\hline Jumlah & 50 & \multicolumn{2}{|c|}{100,0} \\
\hline Paritas & Jumlah (n) & \multicolumn{2}{|c|}{ Persen $(\%)$} \\
\hline Primipara & 21 & \multicolumn{2}{|c|}{42,0} \\
\hline Multipara & 29 & \multicolumn{2}{|c|}{58,0} \\
\hline Jumlah & 50 & \multicolumn{2}{|c|}{100,0} \\
\hline $\begin{array}{c}\text { Variabel Praktek Pemberian } \\
\text { MP-ASI }\end{array}$ & Kategori & $\mathbf{N}$ & $\%$ \\
\hline \multirow{4}{*}{ Sebelum Intervensi } & Baik & 23 & 46,0 \\
\hline & Kurang & 27 & 54,0 \\
\hline & Jumlah & 50 & 100,0 \\
\hline & Baik & 39 & 78,0 \\
\hline \multirow[t]{2}{*}{ Setelah Intervensi } & Kurang & 11 & 22,0 \\
\hline & Jumlah & 50 & 100,0 \\
\hline
\end{tabular}

Tabel 2. Rerata Praktek Pemberian MP-ASI Sebelum dan Setelah Intervensi Pelatihan di Desa Mallusesalo Kabupaten Wajo Tahun 2019

\begin{tabular}{|c|c|c|c|c|}
\hline \multicolumn{2}{|c|}{$\begin{array}{c}\text { Rerata Skor Praktek Pemberian } \\
\text { MP-ASI }\end{array}$} & \multirow{2}{*}{$\begin{array}{c}\Delta \text { Mean } \\
\text { Skor }\end{array}$} & \multirow[t]{2}{*}{$\%$} & \multirow[t]{2}{*}{$p^{*}$} \\
\hline Sebelum & Setelah & & & \\
\hline 19,68 & 24,0 & 4,32 & 21,95 & 0,000 \\
\hline
\end{tabular}

